\title{
IMPLEMENTASI PENGGUNAAN HAK INISIATIF UNTUK MENGHASILKAN PERATURAN DAERAH TENTANG PENGELOLAAN PEDAGANG KAKI LIMA YANG PARTISIPATIF DI KOTA PEKALONGAN
}

\author{
Nurul Indrawati, Djauhari \\ Dosen Fakultas Hukum UNISSULA \\ Djauhari00@yahoo.com
}

\begin{abstract}
The implementation of Act No.32 of 2004 about Local Government gives authority to each region to set up their households through the economic empowerment. One of the local economic development that significantly in contact with the public is with the management of street vendors. Structuring and management of vendors ranging from the provision of public space that does not ignore the rights of other members of society to the preparation of strict regulations should be considered a comprehensive solution including through the use of the right of initiative by members of the the Regional Representatives Council Pekalongan, so it can be known implementations use rights initiative of Parliament as well as the extent of public participation in the legislative drafting process. The method used in this study is a socio-juridical, namely to conduct a review of the legal aspects to know the rules that apply specifically related links use the right of initiative with community participation. Legislative function Legislative Council Pekalongan implementation of the rights owned embodied in the form of local regulations that have been generated. Legislative drafting from the Regional Representatives Council embodies the aspirations of the people against the people's representatives.
\end{abstract}

Keyword : Initiative Rights, Community Participation

\begin{abstract}
Abstrak
Pelaksanaan Undang-Undang Nomor 32 Tahun 2004 Tentang Pemerintahan Daerah memberikan kewenangan kepada setiap daerah untuk mengatur rumah tangganya melalui pemberdayaan ekonomi. Salah satu pengembangan ekonomi lokal yang secara nyata bersinggungan dengan masyarakat adalah dengan adanya pengelolaan pedagang kaki lima. Penataan dan pengelolaan pedagang kaki lima mulai dari penyediaan ruang publik yang tidak mengabaikan hak anggota masyarakat lainnya sampai dengan penyusunan regulasi yang tegas perlu dipikirkan solusi yang komprehensif antara lain melalui penggunaan hak inisiatif oleh anggota Dewan Perwakilan Rakyat Daerah Kota Pekalongan, sehingga dapat diketahui implementasi penggunaan hak inisiatif Dewan Perwakilan Rakyat serta seberapa jauh partisipasi masyarakat dalam proses penyusunan peraturan daerah. Metode yang digunakan dalam penelitian ini adalah yuridis sosiologis, yaitu dengan melakukan peninjauan aspek hukum untuk mengetahui peraturan-peraturan yang berlaku khususnya yang berkaitan keterkaitan penggunaan hak inisiatif dengan partisipasi masyarakat. Fungsi legislasi Dewan Perwakilan Rakyat Daerah Kota Pekalongan diwujudkan terlaksananya hak yang dimiliki dalam bentuk peraturan daerah yang sudah dihasilkan. Penyusunan peraturan daerah yang berasal dari Dewan Perwakilan Rakyat Daerah merupakan perwujudan aspirasi masyarakat terhadap wakil rakyat.
\end{abstract}

Kata Kunci : Hak Inisiatif, Partisipasi Masyarakat. 


\section{A. PENDAHULUAN}

Perubahan terhadap konstitusi telah menempatkan daerah lebih mandiri mengatur kewenangan masing-masing. Dalam UndangUndang Dasar Negara Republik Indonesia 1945, pemerintahan daerah diatur dalam bab tersendiri yaitu dalam Bab VI dengan judul "Pemerintahan Daerah" yang intinya memberikan kewenangan kepada Pemerintah daerah untuk mengatur dan menjalankan roda pemerintahan daerah secara otonomi seluasluasnya, kecuali urusan pemerintahan yang oleh Undang-undang ditentukan sebagai urusan pemerintah pusat. Kewenangan ini diatur lebih khusus dalam Undang-Undang No.22 Tahun 1999 tentang Pemerintahan Daerah yang kemudian dicabut dengan Undang-Undang No.32 Tahun 2004 tentang Pemerintahan Daerah sebagai penyempurnaan dari pemberian kewenangan kepada daerah. Pelimpahan kewenangan otonomi tersebut, ditindaklanjuti oleh daerah dengan membentuk instrumen hukum untuk mengatur daerahnya secara konkret dan penuh bertanggung jawab dalam menentukan dan mengatur urusan rumah tangganya. Demikian pula, di Kota Pekalongan yang membentuk Peraturan Daerah Kota Pekalongan Nomor 2 Tahun 2008 tentang Urusan Pemerintahan Pilihan Yang Menjadi Kewenangan Pemerintahan Daerah Kota Pekalongan (Lembaran Daerah Kota Pekalongan Tahun 2008 Nomor 3).

Kewenangan yang mendasar dari sistem pemerintahan daerah adalah pelimpahan kekuasaan secara politik maupun secara administratif kepada daerah untuk menyelenggarakan kewenangan sesuai dengan prakarsa dan inisiatif masyarakat didaerah selain 6 (enam) kewenangan yang masih menjadi kewenangan pemerintah pusat antara lain politik luar negeri, moneter dan fiskal nasional, agama, pertahanan, keamanan, dan yudisial. Pelimpahan kewenangan itulah yang kita namakan dengan "otonomi daerah". Pelimpahan itu secara otomatis juga memindahkan fokus politik ke daerah karena pusat kekuasaan tidak hanya dimonopoli oleh pemerintah pusat seperti di era sentralisasi namun telah terdistribusi ke daerah. Pelimpahan kewenangan itu disertai pula dengan pemberian kekuasaan yang lebih besar bagi Dewan Perwakilan Rakyat/DPRD dalam menjalankan fungsi Legislasi, Budgeting dan Controling. Karena diharapkan dengan "Otonomi Daerah", Dewan Perwakilan Rakyat Daerah/DPRD mampu meningkatkan peran pembuatan peraturan daerah yang sesuai dengan kebutuhan hukum masyarakat di daerah. Pembentukan peraturan daerah saat ini merupakan kewenangan dewan perwakilan rakyat daerah sesuai dengan fungsi legislasi. Untuk menjalankan fungsi tersebut DPRD telah dipersenjatai dengan seperangkat aturan pendukung sehingga tak pelak menjadikan DPRD sebagai lembaga yang seharusnya mampu menghasilkan produk perundangan yang lebih produktif. Undang-Undang Nomor 32 Tahun 2004 tentang Pemerintahan Daerah telah memberikan kekuasaan membuat Peraturan Daerah (Perda) kepada Dewan Perwakilan Rakyat (DPRD) sebagaimana yang diamanahkan dalam Pasal 41 yaitu "DPRD Kabupaten/Kota mempunyai fungsi:

a. Legislasi;

b. Anggaran; dan

c. Pengawasan. ${ }^{1}$

Penjelasan mengenai ketiga fungsi tersebut sebagai berikut:

a. Fungsi legislasi adalah legislasi daerah yang merupakan fungsi DPRD untuk membentuk peraturan daerah Kabupaten/ Kota bersama Bupati/Walikota;

b. Fungsi anggaran adalah fungsi DPRD Kabupaten/Kota untuk menyusun dan menetapkan APBD yang didalamnya termasuk anggaran untuk pelaksanaan fungsi, tugas dan wewenang DPRD Kabupaten/Kota; dan

c. Fungsi pengawasan adalah fungsi DPRD Kabupaten/Kota untuk melakukan pengawasan terhadap pelaksanaan undang-undang, peraturan daerah dan keputusan Bupati/Walikota serta kebijakan yang ditetapkan oleh pemerintah daerah.

Pasal 42 mengatur tentang tugas dan wewenang DPRD, DPRD Kabupaten/Kota mempunyai tugas dan wewenang:

a. Membentuk peraturan daerah yang dibahas dengan bupati/walikota untuk mendapat persetujuan bersama;

1 Undang-Undang Nomor 32 Tahun 2004 tentang Pemerintahan Daerah 
b. Menetapkan APBD Kabupaten/Kota bersama-sama dengan bupati/walikota;

c. Melaksanakan pengawasan terhadap pelaksanaan peraturan daerah dan peraturan perundangan lainnya, keputusan bupati/walikota, APBD, kebijakan pemerintah daerah dalam melaksanakan program pembangunan daerah, dan kerjasama internasional di daerah;

d. Mengusulkan pengangkatan dan pemberhentian bupati/wakil bupati atau walikota/wakil walikota kepada Menteri Dalam Negeri melalui gubernur;

e. Memberikan pendapat dan pertimbangan kepada pemerintah daerah Kabupaten/Kota terhadap rencana perjanjian internasional yang menyangkut kepentingan daerah; dan

f. Meminta laporan keterangan pertanggungjawaban bupati/walikota dalam pelaksanaan tugas desentralisasi. ${ }^{2}$

Proses transisi menuju perilaku kekuasaan yang transparan, partisipatif dan akuntabel dalam menjalankan kekuasaan membutuhkan instrumen dan instrumen yang paling tepat untuk mewujudkan perubahan itu adalah hukum. Apabila kita menempatkan hukum sebagai alat rekayasa sosial maka tak pelak akan menempatkan peraturan perundang-undangan pada posisi yang sangat penting dalam mengatur tata kekuasaan maupun masyarakat. Dalam hal ini peranan hukum tertulis di tingkat daerah atau peraturan daerah menjadi sangat penting. Penggunaan hukum tertulis sebagai alat rekayasa sosial nampaknya sudah menjadi ciri dari negara hukum modern. Transisi di tingkat daerah seharusnya diprakarsai oleh Dewan Perwakilan Rakyat Daerah (DPRD) melalui inisiasi penyusunan Peraturan Daerah yang berorientasi terutama untuk melakukan perubahan terhadap sistem penyelenggaraan pemerintahan daerah yang transparan, akuntabel dan partisipatif serta melindungi potensi dan kearifan lokal (Local Wisdom) yang ada di daerahnya.

Penggunaan hak inisiatif oleh anggota Dewan Perwakilan Rakyat Daerah, merupakan wujud

2 Undang-Undang Nomor 32 Tahun 2004 tentang Pemerintahan Daerah dari kedaulatan rakyat. Karena prinsip kedaulatan rakyat berasal dari rakyat itu sendiri. Menurut Immanuel Kant: "Tujuan negara itu adalah untuk menegakkan hukum dan menjamin kebebasan dari warga negaranya. Pengertian kebebasan di sini adalah kebebasan dalam batas-batas perundang-undangan. Sedangkan undangundang yang berhak membuat adalah rakyat, karena itu undang-undang adalah penjelmaan dari kemauan atau kehendak rakyat. Jadi rakyatlah yang mewakili kekuasaan tertinggi atau kedaulatan rakyat atau demokratis". ${ }^{3}$ Berdasarkan teori kedaulatan rakyat tersebut, maka penggunaan hak inisiatif yang dilakukan oleh anggota DPRD, merupakan kewajiban moral yang harus dilakukan sebagai pertanggungjawaban mereka terhadap suara yang diberikan oleh konstituen saat Pemilihan Umum.

Tuntutan masyarakat perlu diakomodir dalam penyusunan produk hukum daerah sehingga menghasilkan suatu aturan yang partisipatif. Efek positif pelibatan masyarakat dalam penyusunan aturan tentu akan menimbulkan kesadaran hukum masyarakat menuju tatanan sosial yang taat hukum, akuntabel serta transparan. Masyarakat yang merupakan subyek sekaligus obyek aturan, diharapkan berpartisipasi mulai proses perencanaan, pelaksanaan maupun pengawasan aturan hukum baik secara langsung maupun tidak langsung melalui keterwakilan masyarakat dalam lembaga formal daerah.

Garis besar partisipasi masyarakat menekankan pada hak yang dimiliki masyarakat terlibat dalam proses pembentukan aturan hukum secara demokratis. Untuk mengetahui implementasi penggunaan hak inisiatif DPRD serta seberapa jauh partisipasi masyarakat dalam proses penyusunan peraturan, maka dipilih studi pembahasan penyusunan Peraturan Daerah Kota Pekalongan tentang Pengelolaan Pedagang Kaki Lima. Pemilihan peraturan daerah ini dipandang relevan, di mana di satu sisi peraturan daerah tersebut merupakan prakarsa DPRD yang langsung berhubungan dengan hajat hidup dan gejala sosial ekonomi masyarakat sementara di sisi yang lain partisipasi masyarakat sangat diharapkan untuk menentukan kehidupan yang

3 Soehino, 1980, IImu Negara, Liberty, Yogjakarta, hlm.161 
lebih baik. Bertitik tolak dari beberapa uraian dan berdasarkan permasalahan di atas, penulis tertarik untuk membahas dan menelitinya dengan mengambil judul Implementasi Penggunaan Hak Inisiatif untuk Menghasilkan Peraturan Daerah tentang Pengelolaan Pedagang Kaki Lima yang Partisipatif di Kota Pekalongan (Studi Penyusunan Peraturan Daerah tentang Pengelolaan Pedagang Kaki Lima). Berdasarkan latar belakang permasalahan yang telah dikemukakan, maka dapat dirumuskan beberapa masalah sebagai berikut:

1. Bagaimanakah implementasi penggunaan hak inisiatif DPRD Kota Pekalongan dalam menghasilkan Peraturan Daerah tentang Pengelolaan Pedagang Kaki Lima yang partisipatif?

2. Bagaimanakah proses penyusunan Peraturan Daerah tentang Pengelolaan Pedagang Kaki Lima yang partisipatif di Kota Pekalongan?

\section{B. METODE PENELITIAN}

Metode yang digunakan dalam penelitian ini adalah yuridis sosiologis, yaitu dalam penelitian ini Penulis melakukan peninjauan dari aspek hukumnya untuk mengetahui peraturan-peraturan yang berlaku khususnya yang berkaitan keterkaitan penggunaan hak inisiatif dengan partisipasi masyarakat. Untuk pendekatan yuridis dalam penelitian ini dimaksudkan untuk membahas peraturan perundang-undangan yang memberikan amanah kepada Dewan Perwakilan Rakyat Daerah dalam menggunakan hak inisiatif, sedangkan pendekatan sosiologis dimaksudkan untuk melihat partisipasi masyarakat dalam penyusunan suatu aturan daerah.

\section{HASIL PENELITIAN DAN PEMBAHASAN}

1. Implementasi penggunaan hak inisiatif DPRD Kota Pekalongan dalam menghasilkan Peraturan Daerah tentang Pengelolaan Pedagang Kaki Lima yang partisipatif

Pelaksanaan fungsi dan wewenang DPRD Kota Pekalongan melahirkan visi DPRD Kota Pekalongan adalah "mewujudkan lembaga perwakilan rakyat yang demokratis, aspiratif, transparan dan akuntabel menuju masyarakat sejahtera lahir batin yang diridhoi Allah Yang Maha Kuasa". ${ }^{4}$

DPRD Kota Pekalongan merupakan representasi rakyat Kota Pekalongan mempunyai hak mengajukan rancangan peraturan daerah sebagaimana diatur dalam beberapa ketentuan peraturan perundang-undangan, yaitu:

1. Undang-Undang Nomor 27 Tahun 2009 tentang Majelis Permusyawaratan Rakyat, Dewan Perwakilan Rakyat, Dewan Perwakilan Daerah dan Dewan Perwakilan Rakyat Daerah;

2. Undang-Undang Nomor 12 Tahun 2011 tentang Pembentukan Peraturan Perundang-undangan;

3. Peraturan Pemerintah Nomor 16 Tahun 2010 tentang Pedoman Penyusunan Peraturan Dewan Perwakilan Rakyat Daerah tentang Tata Tertib Dewan Perwakilan Rakyat Daerah

4. Peraturan DPRD Kota Pekalongan Nomor 1/DPRD/XII/2012 tentang Tata Tertib DPRD Kota Pekalongan.

Pelaksanaan fungsi legislasi DPRD Kota Pekalongan dapat dilihat dari terlaksananya hak yang dimiliki dalam bentuk peraturan daerah yang sudah dihasilkan baik berasal dari Walikota maupun prakarsa DPRD periode 20092014. Sedangkan dalam mengadakan perubahan terhadap Raperda, dapat dilakukan dalam proses pembahasan Raperda oleh DPRD bersama Walikota. Hasil wawancara dengan responden Ketua DPRD Kota Pekalongan, dapat diketahui bahwa yang menjadi pertimbangan bagi DPRD dalam menghasilkan peraturan daerah prakarsa DPRD adalah: ${ }^{5}$

1. Peraturan daerah yang dibuat merupakan amanat peraturan yang lebih tinggi;

4 Sekretariat DPRD Kota Pekalongan, 2011, Selayang Pandang Masa Lalu dan Kini, h. 9.

5 Wawancara dengan Ketua DPRD Kota Pekalongan, H. M. Bowo Leksono, Ah.T, SH, MM, MH pada tanggal 2 Juli 2013 
2. Peraturan daerah tidak bertentangan dengan peraturan perundangundangan yang lebih tinggi;

3. Peraturan daerah berdasarkan dan tidak terlalu memberatkan kepada masyarakat,

4. Peraturan daerah sesuai dengan kondisi objektif di daerah dengan memperhatikan aspek muatan lokal;

5. Pertimbangan ketersediaan anggaran dalam pembahasan peraturan daerah maupun pelaksanaan peraturan daerah;

6. Pertimbangan sarana pendukung pelaksanaan peraturan daerah sehingga peraturan daerah dapat optimal keberlakuannya;

7. Peraturan daerah yang dibuat tidak merugikan kepada pemerintah daerah baik dalam jangka waktu lama maupun pendek.

Penyusunan Peraturan Daerah tentang Pengelolaan Pedagang Kaki Lima dijabarkan lebih teknis didasarkan pada Peraturan DPRD Kota Pekalongan Nomor 1/DPRD/XII/2012 tentang Tata Tertib DPRD Kota Pekalongan sebagai buku pedoman DPRD dalam melaksanakan fungsi dan wewenangnya, sebagai berikut:

1) Perencanaan Penyusunan Peraturan Daerah

Perencanaan penyusunan peraturan daerah dilaksanakan oleh Badan Legislasi Daerah melalui penyusunan Program Legislasi Daerah sebagai instrumen perencanaan program pembentukan peraturan daerah Provinsi yang disusun secara terencana, terpadu, dan sistematis.

Prolegda tersebut, memuat program pembentukan Peraturan Daerah yang berisi:

a) Judul Rancangan Peraturan Daerah;

b) Materi yang diatur yang telah melalui pengkajian dan penyelarasan yang dituangkan dalam naskah akademik, dan c) Keterkaitannya dengan Peraturan Perundang-undangan lainnya yang merupakan keterangan mengenai konsepsi Rancangan Peraturan Daerah yang meliputi:

1) latar belakang dan tujuan penyusunan;

2) sasaran yang ingin diwujudkan;

3) pokok pikiran, lingkup, atau objek yang akan diatur; dan

4) jangkauandanarahpengaturan. Rancangan peraturan daerah yang menjadi Program Legislasi Daerah Kota Pekalongan Tahun Anggaran 2013, sebagai berikut: ${ }^{6}$

A. Rancangan Peraturan Daerah Usulan DPRD Kota Pekalongan

1. Raperda tentang Larangan Penggunaan Bahan Makanan Berbahaya dalam Makanan dan Minuman.

2. Raperda tentang Pelayanan Penyandang Masalah Kesejahteraan Sosial (PMKS).

3. Raperda tentang Penyusunan Produk-produk Hukum.

4. Raperda tentang Ketertiban Umum.

5. Raperda tentang Tanggung Jawab Sosial Perusahaan.

6. Raperda tentang Pengelolaan Pedagang Kaki Lima.

B. Rancangan Peraturan Daerah Usulan Walikota Pekalongan

1. Raperda tentang Perubahan Peraturan Daerah Nomor 4 Tahun 2011 tentang Pajak Restoran.

2. Raperda tentang Perubahan Peraturan Daerah Nomor 8 Tahun 2011 tentang Pajak Bumi dan Bangunan Perdesaan dan Perkotaan.

3. Raperda tentang Perubahan Atas Peraturan Daerah Nomor 10 Tahun 2010 tentang

6 Sumber: Keputusan Dewan Perwakilan Rakyat Daerah Kota Pekalongan Nomor : 22/DPRD/XI/2012 tentang Penetapan Program Legislasi Daerah Kota Pekalongan Tahun Anggaran 2013 
Rencana Pembangunan Jangka Menengah Daerah Tahun 2010-2015.

4. Raperda tentang Perubahan Ketiga Atas Peraturan Daerah Nomor 3 Tahun 1975 tentang Pendirian PDAM Kota Pekalongan.

5. Raperda tentang Perubahan Atas Peraturan Daerah Nomor 18 Tahun 2006 tentang Perusahaan Daerah Bank Perkreditan Rakyat Bank Pasar Kota Pekalongan.

6. Raperda tentang Rencana Induk Pembangunan Kepariwisataan Kota Pekalongan.

7. Raperda tentang Perubahan Atas Peraturan Daerah Nomor 1 Tahun 2011 tentang Organisasi dan Tata Kerja Perangkat Daerah Kota Pekalongan.

8. Raperda tentang Pembentukan, Penghapusan dan Penggabungan Kelurahan.

9. Raperda tentang Peningkatan Pemberian ASI Ekslusif.

10. Raperda tentang Pertanggungjawaban APBD 2012.

11. Raperda tentang APBD Perubahan Tahun Anggaran 2013.

12. Raperda tentang APBD Penetapan Tahun 2014.

2. Proses Penyusunan Peraturan Daerah Tentang Pengelolaan Pedagang Kaki Lima Yang Partisipatif Di Kota Pekalongan

Rancangan Peraturan Daerah tentang Pengelolaan Pedagang Kaki Lima merupakan salah satu rancangan peraturan daerah prakarsa DPRD yang masuk dalam Program Legislasi Daerah Tahun 2013. Sehingga rancangan peraturan daerah tersebut, menjadi fokus pembahasan rancangan peraturan daerah pada tahun 2013. Sesuai Program Legislasi Daerah, maka Rancangan Peraturan Daerah tentang Pengelolan Pedagang Kaki Lima secara lebih rinci dapat dijelaskan sebagai berikut: ${ }^{7}$

1. Judul

Penulisan judul peraturan daerah, dibuat simple dan mengambarkan isi dari muatan materi peraturan daerah tersebut.

2. Materi Rancangan Peraturan Daerah

a. Konsideran Raperda Kota Pekalongan tentang Pengelolaan Pedagang Kaki Lima baik Menimbang maupun Mengingat.

b. Materi isi

Dalam kerangka penyusunan peraturan daerah selain mencakup judul, pembukaan, juga harus menguraikan mengenai ketentuan batang tubuh.

3. Pengusulan Rancangan Peraturan Daerah

Pelaksanaan hak inisiatif anggota DPRD diwujudkan dengan pengusulan rancangan peraturan daerah diatur dalam Peraturan DPRD Nomor 1/ DPRD/XII/2012 tentang Tata Tertib DRPD Kota Pekalongan sebagai berikut:

(1) Rancangan peraturan daerah yang berasal dari DPRD dapat diajukan oleh anggota DPRD, komisi, gabungan komisi, atau Badan Legislasi Daerah. Rancangan Peraturan Daerah tentang Pengelolaan Pedagang Kaki Lima diusulkan oleh Badan Legislasi Daerah.

(2) Rancangan peraturan daerah yang diajukan oleh anggota DPRD, komisi, gabungan komisi, atau Badan Legislasi Daerah disampaikan secara tertulis kepada pimpinan DPRD

7 Sumber: Naskah Akademik Rancangan Peraturan Daerah tentang Pengelolaan Pedagang Kaki Lima, 2013 
disertai dengan penjelasan atau keterangan dan/atau naskah akademik, daftar nama dan tanda tangan pengusul, dan diberikan nomor pokok oleh sekretariat DPRD.

(3) Rancangan peraturan daerah oleh pimpinan DPRD disampaikan kepada Badan Legislasi Daerah untuk dilakukan pengkajian. Dalam pengkajian tersebut, Badan Legislasi Daerah membahas dasar hukum maupun efek keberlakuan bagi masyarakat.

(4) Pimpinan DPRD menyampaikan hasil pengkajian Badan Legislasi Daerah kepada rapat paripurna DPRD.

(5) Rancangan peraturan daerah yang telah dikaji oleh Badan Legislasi Daerah disampaikan oleh pimpinan DPRD kepada semua anggota DPRD selambatambatnya 7 (tujuh) hari sebelum rapat paripurna DPRD.

(6) Dalam rapat paripurna DPRD:

a. pengusul memberikan penjelasan;

b. fraksi dan anggota DPRD lainnya memberikan pandangan; dan

c. pengusul memberikan jawaban atas pandangan fraksi dan anggota DPRD lainnya.

(7) Rapat paripurna DPRD memutuskan usul rancangan peraturan daerah berupa:

a. persetujuan;

b. persetujuan dengan pengubahan; atau

c. penolakan.

(8) Dalam hal persetujuan dengan pengubahan, DPRD menugasi komisi, gabungan komisi, Badan Legislasi Daerah, atau panitia khusus untuk menyempurnakan rancangan peraturan daerah tersebut.

(9) Rancangan peraturan daerah yang telah disiapkan oleh DPRD disampaikan dengan surat pimpinan DPRD kepada Walikota.

4. Pembahasan Peraturan Daerah

a. Rancangan peraturan daerah yang berasal dari DPRD atau Walikota dibahas oleh DPRD dan Walikota untuk mendapatkan persetujuan bersama.

b. Pembahasan rancangan peraturan daerah, dilakukan melalui 2 (dua) tingkat pembicaraan, yaitu pembicaraan tingkat I dan pembicaraan tingkat II.

c. Pembicaraan tingkat । sebagaimana dimaksud pada ayat (2) meliputi: 1. Dalam hal Raperda berasal dari Walikota

2. Dalam hal Raperda berasal dari DPRD

5. Public Hearing

Pelaksanaan public hearing merupakan sarana menampung dan mendengarkan aspirasi masyarakat terutama stake holder terkait. Public hearing dilaksanakan dengan mengundang stake holder terkait, yaitu unsur DPRD Kota Pekalongan, Dinas terkait, tokoh agama dan masyarakat serta perwakilan pedagang kaki lima. Dalam public hearing tersebut, para pihak memberikan masukan dan menyampaikan aspirasi terhadap kesempurnaan peraturan daerah tersebut.

\section{PENUTUP}

\section{Kesimpulan}

a. Implementasi penggunaan hak inisiatif DPRD Kota Pekalongan dinilai sudah bagus. Hal ini terlihat dari perda yang dihasilkan dari inisiatif DRPD cukup banyak dengan berbagai macam materi pengaturan 
termasuk Peraturan Daerah tentang Pengelolaan Pedagang Kaki Lima.

b. Penyusunan Peraturan Daerah tentang Pengelolaan Pedagang Kaki Lima telah sesuai dengan asas-asas perundang-undangan yang baik, sesuai dengan Undang-undang Republik Indonesia Nomor 12 Tahun 2011 tentang Pembentukan Peraturan Perundang-undangan. Pelibatan masyarakat telah diterapkan dalam Penyusunan Peraturan Daerah tentang Pengelolaan Pedagang Kaki Lima oleh DPRD yang terdapat pada: pengusulan rancangan peraturan daerah; proses penyusunan peraturan perundangundangan secara terencana, terpadu dan sistematis sampai pengawasan peraturan daerah.

\section{Saran}

a. Anggota DPRD dalam melaksanakan fungsi legislasi agar lebih berpihak kepada masyarakat, sesuai dengan keberadaan mereka sebagai wakil rakyat. Tidak hanya memikirkan ketersediaan dana bagi kelancaran tugas mereka, atau peningkatan anggaran untuk kesejahteraan mereka dan eksekutif atau bahkan unsur kepentingan politik semata.

b. Perlu penelitian dan pengkajian lebih lanjut tentang pelaksanaan fungsi legislasi terutama hak inisiatif DPRD Kota Pekalongan, agar apa yang dicita-citakan atau diharapkan oleh masyarakat terhadap anggota DPRD terlaksana sebagaimana mestinya.

\section{DAFTAR PUSTAKA}

\section{- Buku-buku}

Bambang, Yudoyono, 2011, Otonomi Daerah Desentralisasi dan Pengembangan SDM Aparatur Pemda dan Anggota DPRD, Pustaka Sinar Harapan, Jakarta.

Mirza Nasution, 2008, Perubahan Pertanggungjawaban Gubernur dalam Penyelenggaraan Pemerintahan Daerah Berdasarkan UUD 1945, Disertasi Program Pascasarjana Ilmu Hukum Universitas Sumatera Utara, Medan.

Sekretariat DPRD Kota Pekalongan, 2011, Selayang Pandang Masa Lalu dan Kini

Sekretariat DPRD Kota Pekalongan, Naskah Akademik Rancangan Peraturan Daerah tentang Pengelolaan Pedagang Kaki Lima, 2013

Sekretariat DPRD Kota Pekalongan, Keputusan Dewan Perwakilan Rakyat Daerah Kota Pekalongan Nomor: 22/DPRD/XI/2012 tentang Penetapan Program Legislasi Daerah Kota Pekalongan Tahun Anggaran 2013

Soehino, 1980, IImu Negara, Liberty, Yogjakarta

\section{- Peraturan Perundang-undangan}

Undang-Undang Dasar Negara Republik Indonesia Tahun 1945.

Undang-Undang Nomor 32 Tahun 2004 tentang Pemerintahan Daerah

Undang-Undang Nomor 12 Tahun 2011 tentang Pembentukan Peraturan Perundang-undangan

Peraturan Menteri Dalam Negeri Nomor 41 Tahun 2012 tentang Pedoman Penataan dan Pemberdayaan Pedagang Kaki Lima

Peraturan Daerah Kota Pekalongan Nomor 2 Tahun 2008 tentang Urusan Pemerintahan

Pilihan Yang Menjadi Kewenangan Pemerintahan Daerah Kota Pekalongan (Lembaran

Daerah Kota Pekalongan Tahun 2008 Nomor 3).

Peraturan Walikota Nomor 15 tahun 2006 tentang Penataan Pedagang Kaki Lima. 